\title{
Short communication: Use of fecal starch concentration as an indicator of dry feed digestion in preweaned dairy calves
}

\author{
T. S. Dennis, ${ }^{1}$ W. Hu, F. X. Suarez-Mena, T. M. Hill, J. D. Quigley, and R. L. Schlotterbeck \\ Nurture Research Center, Provimi North America, Brookville, OH 45309
}

\begin{abstract}
Fecal starch (FS) has been used as a tool to evaluate starch and diet digestibility in lactating dairy cows and feedlot steers. Some on-farm advisors also use FS to evaluate calf starter digestibility in preweaned dairy calves. Our objective was to evaluate the influence of starter intake (SI), starch and organic matter digestibility, milk replacer (MR) feeding rate, and age on FS concentrations in preweaned dairy calves. Male Holstein calves ( $43 \pm 2.9 \mathrm{~kg}$ of body weight; $\mathrm{n}=35$ ) from a single farm were fed different amounts of MR ranging from 0.44 to $1.10 \mathrm{~kg}$ of dry matter (DM) daily (27\% crude protein, $17 \%$ fat) and weaned by $7 \mathrm{wk}$ of age. Starter ingredient composition was $37 \%$ whole corn, $20 \%$ whole oats, $35 \%$ protein pellet, and $3 \%$ molasses and contained $43 \pm 1.9 \%$ starch. Fecal grab samples were taken at $3(\mathrm{n}=20), 6(\mathrm{n}=20)$, and $8 \mathrm{wk}(\mathrm{n}=$ 35 ) of age. Twelve fecal samples per calf were taken via rectal palpation over a 5-d period each week, frozen daily, combined on an equal wet-weight basis, and subsampled for analysis. Chromic oxide was used as an external digestibility marker at 3 and $6 \mathrm{wk}$ (included in MR), whereas acid-insoluble ash was used as an internal marker at 8 wk. Milk replacer and starter intakes (offered and refused) were recorded daily during collection periods. Multiple and linear regression of organic matter digestibility (\% of DM), total-tract starch digestibility (TTSD; \% of DM), MR intake (kg/d), SI $(\mathrm{kg} / \mathrm{d})$, and age (week) versus FS (\% of fecal DM) were determined using PROC REG of SAS (version 9.2, SAS Institute Inc., Cary, NC). Prior to weaning, SI, age, and MR rate explained $89 \%$ of the variation in TTSD, where TTSD $=[19.7 \times \mathrm{SI}( \pm 4.25)]+[3.8 \times$ age $( \pm 0.79)]-[24.8 \times$ $\mathrm{MR}( \pm 3.19)]+56.2( \pm 3.39)$. At 3 wk of age, TTSD increased (coefficient of determination $=0.53$ ) and SI decreased (coefficient of determination $=0.20$ ) with increasing FS. At 6 wk of age, TTSD and SI were unrelated to FS. In 8-wk-old calves (with 2 trials), SI, MR
\end{abstract}

Received December 9, 2016.

Accepted April 9, 2017.

${ }^{1}$ Corresponding author: tdennis@provimi-na.com rate, FS, and trial explained $92 \%$ of the variation in TTSD, where TTSD $=-[2.6 \times \mathrm{SI}( \pm 0.67)]-[2.4 \times \mathrm{MR}$ $( \pm 0.56)]-[0.6 \times \mathrm{FS}( \pm 0.04)]+[1.1 \times \operatorname{trial}( \pm 0.33)]+$ 100.4 ( \pm 1.02$)$. Postweaning, TTSD decreased linearly as FS increased (coefficient of determination $=0.86$ ), whereas FS and SI were unrelated, a relationship in contrast to the previously observed result in calves still consuming milk replacer. In the current study, FS was not a good estimate of TTSD or dry feed intake in the preweaned calf, but has potential for evaluating TTSD in calves after weaning.

Key words: fecal starch, digestibility, calf

\section{Short Communication}

Improved diet digestibility, particularly when feeding expensive diets, is prudent in dairy heifer diets. Compared with other stages of production, starter feeds offered to calves preweaning are typically the most expensive dry feeds fed to heifers. On-farm tools used to evaluate diet digestibility can be useful for gauging efficiency of feed use in young heifers as dry feed intake increases. Fecal starch (FS) and total-tract starch digestibility (TTSD) have a close, linear relationship in feedlot cattle (Owens et al., 1986; Zinn et al., 2007) and lactating cows (Fredin et al., 2014); thus, FS has been used as a tool to evaluate digestibility on-farm. Recent anecdotal evidence has indicated the relationship between FS and TTSD is being used to gauge starch utilization from calf starter. Little evidence is available correlating FS with diet and starch digestibility preweaning; however, several studies have reported FS immediately postweaning. Veira et al. (1980) used 9- to 12-wk-old male Holstein calves to evaluate the effect of increasing $\mathrm{CP}$ content by substituting soybean meal for cracked corn (dietary starch declined from 64 to $54 \%$ of DM) and observed that FS declined from 28 to $22 \%$ of fecal DM as corn was removed from a diet including $7.5 \%$ straw. Khan et al. (2008) evaluated barley, corn, oats, and wheat in pelleted calf starters containing $25 \%$ starch with no forage fed and reported more daily FS output with greater DMI in 9-wk-old weaned calves; when calves were consuming $2.8 \mathrm{~kg} / \mathrm{d}$ of DM of a corn- 
based starter, fecal starch output was $59 \mathrm{~g} / \mathrm{d}$ compared with $49 \mathrm{~g} / \mathrm{d}$ for calves consuming $2.2 \mathrm{~kg} / \mathrm{d}$ of DM of an oat-based starter. However, TTSD was similar across treatments, averaging $88 \%$ with a range of 6.5 to $7.8 \%$ FS for calves fed corn compared with oat-based starters, respectively (Khan et al., 2008). From these studies, it appears FS starch may be related more to DMI than TTSD in calves 9 to 12 wk of age. The same trend may also occur for preweaned calves with lesser rumen and lower gut development. Therefore, our research objective was to evaluate FS as a proxy for estimating starch and starter digestibility in preweaned calves over time.

Calves were cared for by acceptable practices as described in the Guide for the Care and Use of Agricultural Animals in Research and Teaching (FASS, 2010). Male Holstein calves, initially 2 to $4 \mathrm{~d}$ of age and $43 \pm 2.9 \mathrm{~kg}$ of BW from a single dairy farm, were transported $3.5 \mathrm{~h}$ to the Nurture Research Center in southwest Ohio during summer and fall of 2013. Calves were housed in 1.2 $\times 2.4 \mathrm{~m}$ individual pens with a coarse rock, tile-drained floor bedded with straw in a curtain-sided, naturally ventilated barn with no added heat. Management practices, including vaccines and medical treatments during the trial, were based on the recommendations of a veterinarian. Fecal grab samples were taken at $3(\mathrm{n}=$ 20), $6(\mathrm{n}=20)$, and $8 \mathrm{wk}(\mathrm{n}=35)$ of age. Twelve fecal samples per calf were taken via rectal palpation over a 5 -d period, each week representing $2 \mathrm{~h}$ intervals of the 24-h day. Fecal samples were frozen daily, combined on an equal wet weight basis at the end of the week's sampling period, and subsampled for analysis. A composite of 12 fecal samples over a 5 -d period was used to reduce variation compared with using individual samples. In the first trial $(\mathrm{n}=20)$, milk replacer $(\mathbf{M R})$ was fed at 2 rates and a common texturized starter with whole corn and oats was fed. A moderate rate of MR was fed at $0.66 \mathrm{~kg}$ of DM reconstituted to $13 \%$ solids for $49 \mathrm{~d}$. A high rate of MR was fed at $0.66 \mathrm{~kg}$ of DM for $4 \mathrm{~d}$, at $0.96 \mathrm{~kg}$ of DM for $4 \mathrm{~d}$, at $1.31 \mathrm{~kg}$ of DM for $34 \mathrm{~d}$, and $0.66 \mathrm{~kg}$ of $\mathrm{DM}$ for the last $7 \mathrm{~d}$. At the high rate, MR was reconstituted to $15 \%$ solids for the first $42 \mathrm{~d}$, then $13 \%$ solids for the last $7 \mathrm{~d}$. For each MR feeding rate, $\mathrm{MR}$ was divided into 2 equal meals at 0630 and $1600 \mathrm{~h}$. In the second trial $(\mathrm{n}=15), 3 \mathrm{MR}$ rates were fed with a common texturized starter with whole corn and oats. A low rate of $\mathrm{MR}$ was fed at $0.44 \mathrm{~kg}$ of DM for $42 \mathrm{~d}$, a moderate rate of MR at $0.66 \mathrm{~kg}$ of $\mathrm{DM}$ for $42 \mathrm{~d}$, and high rate of $\mathrm{MR}$ at $0.66 \mathrm{~kg}$ of $\mathrm{DM}$ for $5 \mathrm{~d}, 0.87 \mathrm{~kg}$ of DM for $37 \mathrm{~d}$, and $0.43 \mathrm{~kg}$ of DM for $7 \mathrm{~d}$. The low and moderate rates were reconstituted to $13 \%$ solids and high rate to $15 \%$ solids. In each trial, MR fed at moderate and high MR rates contained $27 \% \mathrm{CP}$ and $17 \%$ fat on a DM basis. In the second trial, the MR fed at the low rate contained $21 \pm 0.5 \% \mathrm{CP}$ and $21 \pm 1.2 \%$ fat on a DM basis. All texturized starters used in these trials contained $37 \%$ whole corn, $20 \%$ whole oats, $35 \%$ protein pellet, and $3 \%$ molasses and contained $20 \pm 0.8 \%$ $\mathrm{CP}, 8 \pm 0.2 \% \mathrm{ADF}, 15 \pm 0.3 \% \mathrm{NDF}$, and $43 \pm 1.9 \%$ starch. Chromic oxide was used as an external digestibility marker at 3 and 6 wk (included in MR), whereas acid-insoluble ash was used as an internal marker at 8 wk. The MR containing chromic oxide was fed for $7 \mathrm{~d}$ before and through the 2 different 5 -d collection periods. Chromic oxide concentrations in MR $(0.25 \%$ on as-fed basis) were established to achieve an intake of approximately $2 \mathrm{~g}$ or more of chromic oxide per calf daily, exceeding the minimum suggested $1 \mathrm{~g} / \mathrm{d}$ per calf for digestibility estimates (Bouchard et al., 1973). Milk replacer and starter fed and refused was recorded daily. Diet nutrient concentrations were calculated using total intake of MR and starter for each calf at 3 and 6 wk of age and starter intake only at 8 wk of age.

Starter feed and MR composite samples were analyzed [per AOAC International (2000) unless otherwise noted] for DM (oven method 930.15), ash (muffle furnace method 923.03), CP (Kjeldahl method 988.05), fat (alkaline treatment with Röse-Gottlieb method 932.06 for MR; diethyl ether extraction method 2003.05 for starters), starch ( $\alpha$-amylase method; Hall, 2009), NDF with ash by the procedure of Van Soest et al. (1991) without sodium sulfite or $\alpha$-amylase, and ADF with ash (Robertson and Van Soest, 1981). Composites of fecal samples were analyzed for DM, ash, and starch as described above. The MR and fecal samples from 3 and 6 wk of age were analyzed for $\mathrm{Cr}$ (AOAC International, 2000; method 993.14). Starter and fecal samples from 8 wk of age were analyzed for acid-insoluble ash (Van Keulen and Young, 1977). Measured concentrations of digestibility markers ( $\mathrm{Cr}$ or acid-insoluble ash) in feed and feces and DMI were used to estimate fecal output and apparent digestibility of $\mathrm{OM}$ and starch.

Potential relationships between OM digestibility (\% of DM) or starch digestibility (\% of DM) and independent variables such as MR intake $(\mathrm{kg} / \mathrm{d})$, SI $(\mathrm{kg} / \mathrm{d})$, or age (week) were examined using PROC REG with stepwise regression procedures of SAS (version 9.2, SAS Institute Inc., Cary, NC). Data for calves at $8 \mathrm{wk}$ of age from 2 trials were pooled together for analysis and the effect of trial was included as a variable in equation evaluation. Correlation coefficients of FS concentration with chemical composition, MR intake, SI, age, and digestibility were analyzed using the PROC CORR procedure of SAS. Statistical significance was declared at $P \leq 0.05$.

Preweaning, multiple regression showed OM digestibility (OMD) could be predicted by MR feeding rate $(P<0.001)$ and FS $\left(P<0.01 ; \mathrm{R}^{2}=0.38\right)$, whereas TTSD could be predicted by SI $(P<0.001)$, MR feed- 
Table 1. Multiple linear regression equations of OM and starch digestibility with starter intake (SI), milk replacer (MR) feeding rate, age, fecal starch (FS), and trial (8 wk only) in 3-, 6-, and 8-wk-old dairy calves

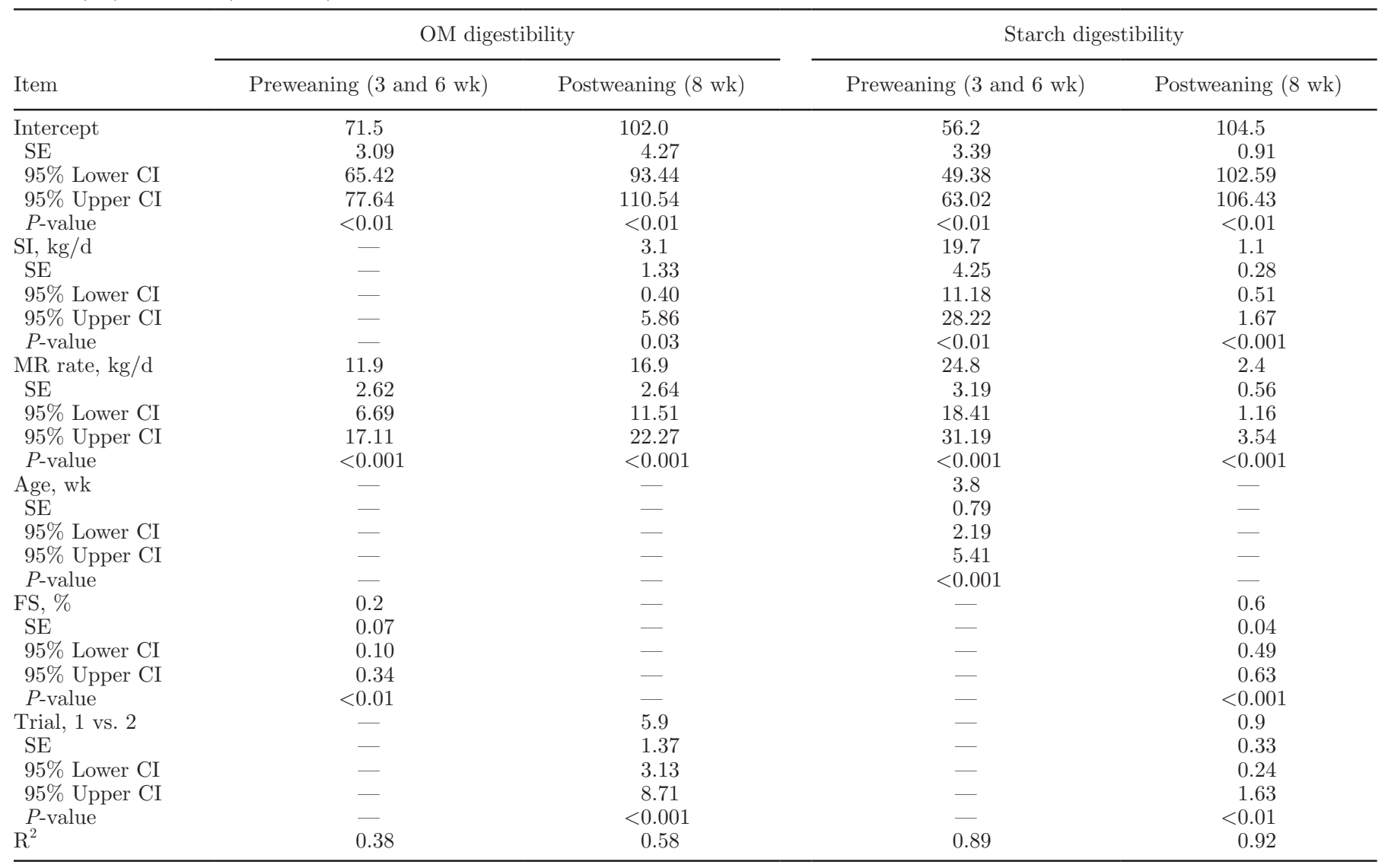

ing rate $(P<0.001)$, and age $\left(P<0.001 ; \mathrm{R}^{2}=0.89\right.$; Table 1). The linear relationship of TTSD with FS was also significant during the entire preweaning period $\left(\mathrm{R}^{2}\right.$ $=0.40 ; P<0.01 ;$ Figure 1). However, TTSD increased linearly with increasing FS at 3 wk of age $\left(\mathrm{R}^{2}=0.53 ; P\right.$ $<0.001)$, whereas we found no significant relationship detected at 6 wk of age $\left(\mathrm{R}^{2}=0.14 ; P=0.16\right)$. Contrary to TTSD, the relationship of OMD with FS was not significant during the entire preweaning period $(P=$ $0.25)$ or at $3 \mathrm{wk}$ of age $(P=0.91$; Table 2$)$; however, at 6 wk of age, OMD increased with increasing FS $\left(\mathrm{R}^{2}\right.$ $=0.45 ; P<0.001)$. Interestingly, FS was negatively correlated with MR feeding rate at $3 \mathrm{wk}$, but not 6 or 8 wk of age (Table 3). Fecal starch was also negatively correlated with diet $\mathrm{CP}$ and ME content at $3 \mathrm{wk}$ of age; however, FS was positively correlated with diet starch, NDF, and ADF content and starch and NDF digestibility at 3 wk of age. Around weaning at 6 wk of age, correlation of FS with diet composition declined, but still tended to be significant (Table 3). In contrast to the relationship observed at 3 wk of age, OMD was positively correlated with FS at 6 wk of age. In weaned calves, where data from 2 trials are available at $8 \mathrm{wk}$ of age, multiple regression showed OMD could be predicted from SI $(P<0.03)$, MR rate $(P<0.001)$, and trial $\left(P<0.001 ; \mathrm{R}^{2}=0.58\right)$, whereas TTSD could be predicted by SI $(P<0.001)$, MR rate $(P<0.001)$, FS $(P<0.001)$, and trial $\left(P<0.01 ; \mathrm{R}^{2}=0.89\right)$. Additionally, TTSD decreased linearly as FS increased $(P$ $<0.01 ; \mathrm{R}^{2}=0.86$; Figure 1); however, OMD was not significantly related to FS postweaning $(P=0.51)$.

In feedlot steers fed high-concentrate diets, corn processing can influence starch digestibility and shift the site of starch digestion from the rumen to the lower gut (Corona et al., 2006). Particle size and starch vitreousness may also influence starch digestion in high-corn diets fed to feedlot cattle (Owens et al., 1986); this typically results in reduced TTSD, which is associated with greater FS in feedlot cattle (Owens et al., 1986; Corona et al., 2006; Zinn et al., 2007). The relationship in feedlot cattle was similar to what we observed in 8-wk-old weaned dairy calves in the current trials fed an all-concentrate diet with whole corn and oats. The negative relationship of starch digestibility with SI and previous MR feeding rate was logical at $8 \mathrm{wk}$ of age. Increased intake can lead to increased passage 


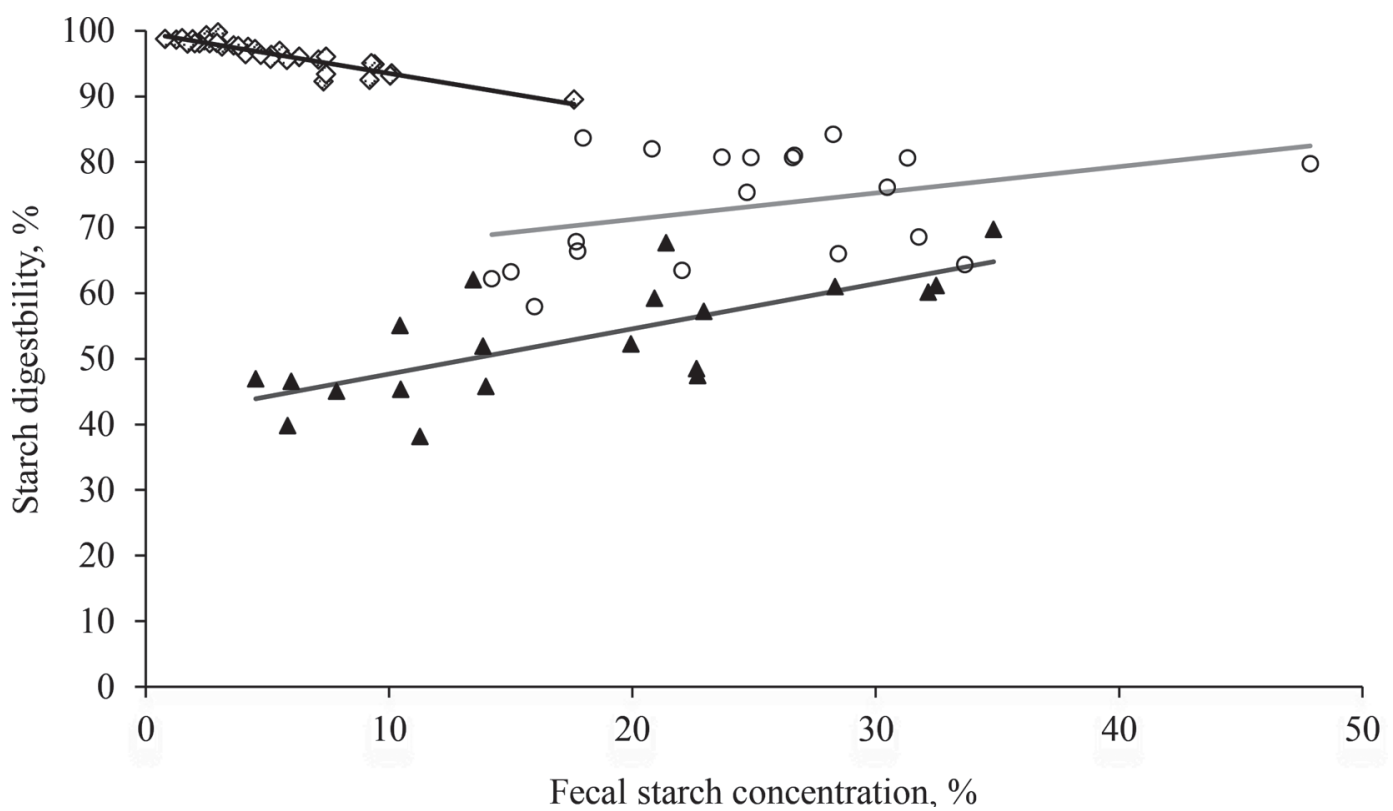

Figure 1. Relationship of starch digestibility to fecal starch concentration in calves measured at 3, 6 , and 8 wk of age. Three weeks ( $\mathbf{\Delta}$ ): starch digestibility $(\%)=0.689 \times$ fecal starch concentration $(\%)+40.795$ (linear $\left.P<0.001 ; \mathrm{R}^{2}=0.525 ; \mathrm{n}=20\right)$. Six weeks $(\bigcirc)$ : starch digestibility $(\%)=0.402 \times$ fecal starch concentration $(\%)+63.209$ (linear $P=0.105 ; \mathrm{R}^{2}=0.139 ; \mathrm{n}=20$ ). Eight weeks (across 2 trials; $\left.\diamond\right)$ : starch digestibility $(\%)=-0.618 \times$ fecal starch concentration $(\%)+99.683\left(\right.$ linear $P<0.001 ; \mathrm{R}^{2}=0.857 ; \mathrm{n}=35$ ).

rates, thereby influencing starch digestibility and site of starch digestion (Gressley et al., 2011). Increased MR feeding rates have been reported to reduce digestion of starch after weaning through what appears to be a delay in rumen development (Terré et al., 2007a,b) from feeding more MR (Terré et al., 2007a,b; Suarez-

Table 2. Linear regression relationship of OM and starch digestibility with dietary or fecal starch concentration in 3-, 6-, and 8-wk-old dairy calves

\begin{tabular}{|c|c|c|c|c|c|c|}
\hline \multirow[b]{2}{*}{ Item } & \multicolumn{3}{|c|}{ OM digestibility } & \multicolumn{3}{|c|}{ Starch digestibility } \\
\hline & $3 \mathrm{wk}$ & $6 \mathrm{wk}$ & $8 \mathrm{wk}$ & $3 \mathrm{wk}$ & $6 \mathrm{wk}$ & $8 \mathrm{wk}$ \\
\hline \multicolumn{7}{|c|}{ Dietary starch, $\%$ of DM } \\
\hline Intercept & 89.188 & 86.887 & 54.534 & 42.882 & 55.416 & 56.591 \\
\hline $\mathrm{SE}$ & 1.780 & 1.727 & 24.704 & 1.748 & 1.619 & 10.281 \\
\hline $95 \%$ Lower CI & 85.448 & 83.258 & 4.274 & 39.209 & 52.015 & 35.675 \\
\hline $95 \%$ Upper CI & 92.928 & 90.515 & 104.975 & 46.555 & 58.817 & 77.508 \\
\hline$P$-value & $<0.001$ & $<0.001$ & 0.034 & $<0.001$ & $<0.001$ & $<0.001$ \\
\hline Linear & -0.495 & -0.060 & 0.508 & 1.554 & 1.082 & 0.953 \\
\hline $\mathrm{SE}$ & 0.219 & 0.096 & 0.590 & 0.215 & 0.090 & 0.246 \\
\hline 95\% Lower CI & -0.955 & -0.261 & -0.692 & 1.103 & 0.893 & 0.453 \\
\hline 95\% Upper CI & -0.036 & 0.141 & 1.709 & 2.006 & 1.270 & 1.453 \\
\hline$P$-value & 0.036 & 0.540 & 0.395 & $<0.001$ & $<0.001$ & $<0.001$ \\
\hline $\mathrm{R}^{2}$ & 0.222 & 0.021 & 0.022 & 0.744 & 0.890 & 0.313 \\
\hline \multicolumn{7}{|c|}{ Fecal starch, $\%$ of DM } \\
\hline Intercept & 86.202 & 79.465 & 76.604 & 40.795 & 63.209 & 99.683 \\
\hline $\mathrm{SE}$ & 2.617 & 1.773 & 1.444 & 3.089 & 6.176 & 0.273 \\
\hline $95 \%$ Lower CI & 80.704 & 75.740 & 73.666 & 34.305 & 50.234 & 99.126 \\
\hline $95 \%$ Upper CI & 91.700 & 83.190 & 79.541 & 47.286 & 76.183 & 100.239 \\
\hline$P$-value & $<0.001$ & $<0.001$ & $<0.001$ & $<0.001$ & $<0.001$ & $<0.001$ \\
\hline Linear & -0.014 & 0.258 & -0.156 & 0.689 & 0.402 & -0.618 \\
\hline $\mathrm{SE}$ & 0.131 & 0.068 & 0.232 & 0.154 & 0.236 & 0.044 \\
\hline $95 \%$ Lower CI & -0.289 & 0.115 & -0.628 & 0.365 & -0.093 & -0.707 \\
\hline $95 \%$ Upper CI & 0.260 & 0.400 & 0.317 & 1.013 & 0.898 & -0.528 \\
\hline$P$-value & 0.914 & 0.001 & 0.508 & $<0.001$ & 0.105 & $<0.001$ \\
\hline $\mathrm{R}^{2}$ & 0.001 & 0.445 & 0.013 & 0.525 & 0.139 & 0.857 \\
\hline
\end{tabular}


Table 3. Pearson correlation coefficients between fecal starch concentration at 3, 6, and 8 wk with chemical composition, milk replacer (MR) rate, and digestibility of $\mathrm{OM}$, starch, NDF, and $\mathrm{ADF}$

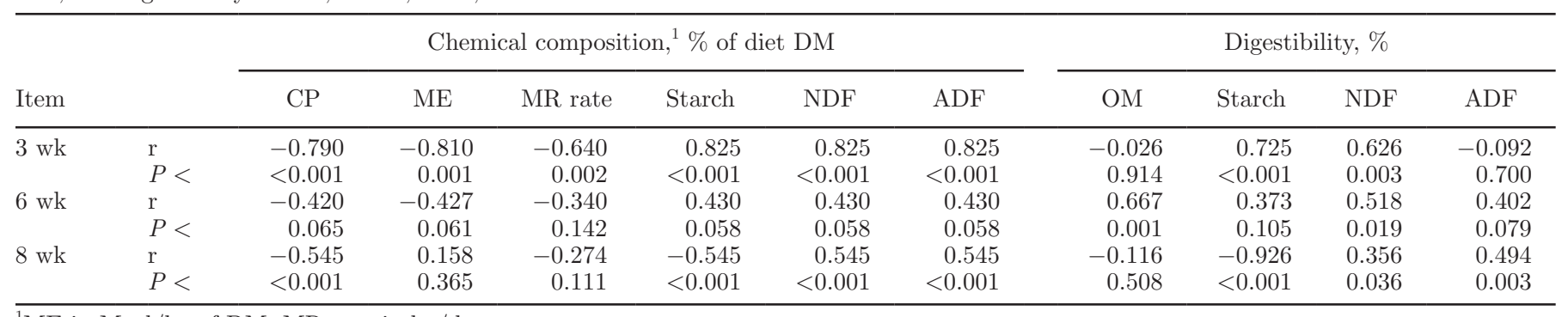

${ }^{1} \mathrm{ME}$ in Mcal/kg of DM; MR rate in $\mathrm{kg} / \mathrm{d}$.

Mena et al., 2011). The lack of any meaningful linear relationship of FS with OMD at 8 wk of age points to issues with using FS to evaluate starter digestibility. Starters fed in the current study were high in starch $(38$ to $43 \%$ of DM) and low in fiber (15\% NDF); thus, if FS gave an accurate representation of starter digestibility, it would be expected to work when evaluating high starch feeds. Some starters fed in the United States are 10 to 20\% starch (Hill et al., 2012); therefore, more data are needed comparing varying levels of starch to evaluate FS as a proxy of digestion in weaned calves. Additionally, the significance of trial in the model for weaned calves could point to factors other than SI and MR rate influencing TTSD and OMD in weaned calves. Our study also included a small number of observations, meaning more information is needed to characterize this relationship.

Compared with weaned calves, the relationship of TTSD to FS was inversely related and highly variable in preweaned calves (Figure 1). This result seems logical, as pancreatic production of $\alpha$-amylase was shown to be low or nonexistent at birth and increased as starch intake increased with age in calves fed milk supplemented with $0.5 \%$ corn starch (Huber et al., 1961) or milk replacer with concentrate feed containing $74 \%$ corn and $52 \%$ starch (Guilloteau et al., 1985). Starter intake was negatively related to MR feeding rates, which was expected given that many studies have observed a reduction in starter intake with increasing MR allowance (Hill et al., 2006a,b, 2007; Bach et al., 2013). With increasing MR intake, the decrease in TTSD in 3 - and 6-wk-old calves was likely due to low pancreatic $\alpha$-amylase production and delayed rumen development. Direct relationships of feeding rates with rumen development are limited; however, when Kristensen et al. (2007) fed 3.1 to $8.3 \mathrm{~kg}$ of MR per day at a $12.3 \% \mathrm{DM}$ dilution rate and Kosiorowska et al. (2011) fed 3.2 to $6.4 \mathrm{~kg} / \mathrm{d}$ of whole milk, empty reticulorumen weights declined with increasing milk allowance. A reduction in rumen papillae length was also observed for calves fed 1.07 versus $0.67 \mathrm{~kg} / \mathrm{d}$ of MR powder (Suarez-Mena et al., 2011). Increasing starch digestibility with age was likely reflective of the concomitant development of the pancreas and rumen.

Fecal starch also did not provide a good estimate of OMD in preweaned calves in the current study. Fecal starch ranged from 4.5 to $47.9 \%$ in preweaned calves (3 and $6 \mathrm{wk}$ of age) and 0.8 to $17.6 \%$ in postweaned calves. Starter intake was typically low until 3 wk of age, and OM intake from starter was a low proportion of total OM intake until milk was removed from the diet. The high value of $47.9 \%$ FS (Figure 1) was validated with additional laboratory analyses. This observation could be reflective of poor starch digestion in the young calf, the influence of MR feeding on the development of the gastrointestinal tract, variability, or a combination of the previous factors. Feeding rates in excess of 0.68 $\mathrm{kg} / \mathrm{d}$ of MR powder have been shown to reduce OMD in 8- (Chapman et al., 2016) and 11-wk-old (Hill et al., 2016) weaned calves fed texturized calf starters with $37 \%$ whole corn and 40 to $43 \%$ starch. Starter intakes before weaning were lesser for calves fed high-MR feeding rates (Chapman et al., 2016; Hill et al., 2016), likely delaying gastrointestinal development and resulting in greater passage of digestible nutrients to the lower gut.

In the current study, FS had no clear relationship with starch and OM digestibility when calves were fed texturized starter diets with whole grains. Fecal starch was high and variable in the preweaned calf, as influenced by digestive maturity, changes in starter intake with age, and the effect high MR intake had on starter intake. Fecal starch was not a good proxy for OM digestibility in the weaned calf. Fecal starch may have some promise as an indicator of starch digestibility in the weaned calf, but more information is needed to determine how other factors, including starter intake, previous MR intake, grain processing, age, days since weaning, and starch concentration of the diet, influence digestibility. The exercise to use multiple regressions was not to develop prediction equation of digestibility, but to evaluate what factors might influence digestibility, and FS was included as factor. The repeatability 
of using any of our equations to predict starter digestibility will likely be problematic because age and trial were significant in some equations. As more research is reported evaluating digestion in the young calf, a more thorough and accurate representation of the factors influencing digestion might be developed.

\section{REFERENCES}

AOAC International. 2000. Official Methods of Analysis. 17th ed. AOAC International, Arlington, VA.

Bach, A., M. Terré, and A. Pinto. 2013. Performance and health responses of dairy calves offered different milk replacer allowances. J. Dairy Sci. 96:7790-7797.

Bouchard, R., G. J. Brisson, and J. P. Julien. 1973. Nutritive value of bacterial sludge and whey powders for protein in calf milk replacers and on chromic oxide as indicator of digestibility. J. Dairy Sci. 56:1445-1449.

Chapman, C. E., P. S. Erickson, J. D. Quigley, T. M. Hill, H. G. Bateman Ii, F. X. Suarez-Mena, and R. L. Schlotterbeck. 2016. Effect of milk replacer program on calf performance and digestion of nutrients with age of the dairy calf. J. Dairy Sci. 99:2740-2747.

Corona, L., F. N. Owens, and R. A. Zinn. 2006. Impact of corn vitreousness and processing on site and extent of digestion by feedlot cattle. J. Anim. Sci. 84:3020-3031.

FASS. 2010. Guide for the Care and Use of Agricultural Animals in Agricultural Research and Teaching. 3rd ed. Fed. Anim. Sci. Soc., Champaign, IL.

Fredin, S. M., L. F. Ferraretto, M. S. Akins, P. C. Hoffman, and R. D. Shaver. 2014. Fecal starch as an indicator of total-tract starch digestibility by lactating dairy cows. J. Dairy Sci. 97:1862-1871.

Gressley, T. F., M. B. Hall, and L. E. Armentano. 2011. Ruminant nutrition symposium: Productivity, digestion, and health responses to hindgut acidosis in ruminants. J. Anim. Sci. 89:1120-1130.

Guilloteau, P., T. Corring, R. Toullec, and R. Guilhermet. 1985. Enzyme potentialities of the abomasum and pancreas of the calf. II. Effects of weaning and feeding a liquid supplement to ruminant animals. Reprod. Nutr. Dev. 25:481-493.

Hall, M. B. 2009. Analysis of starch, including maltooligosaccharides, in animal feeds: A comparison of methods and a method recommended for AOAC collaborative study. J. AOAC Int. 92:42-49.

Hill, T. M., J. M. Aldrich, R. L. Schlotterbeck, and H. G. Bateman. 2006a. Effects of feeding calves different rates and protein concentrations of twenty percent fat milk replacers on growth during the neonatal period. Prof. Anim. Sci. 22:252-260.

Hill, T. M., J. M. Aldrich, R. L. Schlotterbeck, and H. G. Bateman. 2006b. Effects of feeding rate and concentrations of protein and fat of milk replacers fed to neonatal calves. Prof. Anim. Sci. 22:374381.

Hill, T. M., H. G. Bateman, J. M. Aldrich, and R. L. Schlotterbeck. 2007. Effects of the feeding rate of high protein calf milk replacers. Prof. Anim. Sci. 23:649-655.

Hill, T. M., H. G. Bateman, J. M. Aldrich, and R. L. Schlotterbeck. 2012. High starch coarse grain low fiber starters maximize growth of weaned dairy calves less than 4 months of age. Prof. Anim. Sci. 28:325-331.

Hill, T. M., J. D. Quigley, H. G. Bateman Ii, F. X. Suarez-Mena, T. S. Dennis, and R. L. Schlotterbeck. 2016. Effect of milk replacer program on calf performance and digestion of nutrients in dairy calves to 4 months of age. J. Dairy Sci. 99:8103-8110.

Huber, J. T., N. L. Jacobson, and R. S. Allen. 1961. Digestive enzyme activities in the young calf. J. Dairy Sci. 44:1494-1501.

Khan, M. A., H. J. Lee, W. S. Lee, H. S. Kim, S. B. Kim, S. B. Park, K. S. Baek, J. K. Ha, and Y. J. Choi. 2008. Starch source evaluation in calf starter: II. Ruminal parameters, rumen development, nutrient digestibilities, and nitrogen utilization in Holstein calves. J. Dairy Sci. 91:1140-1149.

Kosiorowska, A., L. Puggaard, M. S. Hedemann, J. Sehested, S. K. Jensen, N. B. Kristensen, P. Kuropka, K. Marycz, and M. Vestergaard. 2011. Gastrointestinal development of dairy calves fed low- or high-starch concentrate at two milk allowances. Animal 5:211-219.

Kristensen, N. B., J. Sehested, S. K. Jensen, and M. Vestergaard. 2007. Effect of milk allowance on concentrate intake, ruminal environment, and ruminal development in milk-fed Holstein calves. J. Dairy Sci. 90:4346-4355.

Owens, F. N., R. A. Zinn, and Y. K. Kim. 1986. Limits to starch digestion in the ruminant small intestine. J. Anim. Sci. 63:1634-1648.

Robertson, J. B., and P. J. Van Soest. 1981. The Detergent System of Analysis and its Application to Human Foods. Cornell University, Ithaca, NY

Suarez-Mena, F. X., T. M. Hill, A. J. Heinrichs, H. G. Bateman II, J. M. Aldrich, and R. L. Schlotterbeck. 2011. Effects of including corn distillers dried grains with solubles in dairy calf feeds. J. Dairy Sci. 94:3037-3044

Terré, M., M. Devant, and A. Bach. 2007a. Effect of level of milk replacer fed to Holstein calves on performance during the preweaning period and starter digestibility at weaning. Livest. Sci. 110:82-88.

Terré, M., M. Devant, and A. Bach. 2007b. Performance and nitrogen metabolism of calves fed conventionally or following an enhancedgrowth feeding program during the preweaning period. Livest. Sci. 105:109-119.

Van Keulen, J. V., and B. A. Young. 1977. Evaluation of acid insoluble ash as a natural marker in ruminant digestibility studies. J. Anim. Sci. 44:282-287.

Van Soest, P. J., J. B. Robertson, and B. A. Lewis. 1991. Methods for dietary fiber, neutral detergent fiber, non-starch polysaccharides in relation to animal nutrition. Symposium: carbohydrate methodology, metabolism and nutritional implications in dairy cattle. J. Dairy Sci. 74:3583-3597.

Veira, D. M., G. K. Macleod, J. H. Burton, and J. B. Stone. 1980. Nutrition of the weaned Holstein calf. II. Effect of dietary protein level on nitrogen balance, digestibility and feed intake. J. Anim. Sci. 50:945-951.

Zinn, R. A., A. Barreras, L. Corona, F. N. Owens, and R. A. Ware 2007. Starch digestion by feedlot cattle: Predictions from analysis of feed and fecal starch and nitrogen. J. Anim. Sci. 85:1727-1730. 